\title{
LEWIS FREDERICK HOVIL
}

WE record, with the greatest regret, the death on 6 July 1946, a few weeks before his $8 \mathrm{rst}$ birthday, of Lewis Frederick Hovil, until his retirement in 1930 Actuary and Secretary to and subsequently a Director of the National Provident Institution.

Hovil was educated at Christ's College, Finchley. In 1882 he joined the staff of the Clerical, Medical and General, and in 1888 , the year of his passing the Intermediate Examination of the Institute of Actuaries, was appointed Chief Clerk at the London Office of the Scottish Amicable. He passed the Fellowship Examination in 1890 and in the same year was appointed Assistant Actuary of the Economic. In 1898 he became Assistant Actuary of the National Provident Institution, with which Office he was associated until his death, being appointed Actuary and Secretary in 1904 and a Director on his retirement in 1930.

Hovil held every important office in the Institute of Actuaries except that of President. He served on the Council for I4 years, was Honorary Secretary for the years 1910-12, Vice-President 1913-16, Treasurer $1920-22$. He was an Examiner on four occasions. He was Chairman of the Life Offices' Association for the years $1918-20$. He became a member of the Actuaries Club in 1903 and was Treasurer of the Club from 1913 to 1917 .

He was of a somewhat retiring disposition. His outlook was eminently sound; he was a wise counsellor and was always willing to give advice and help to the younger members of the profession. His principal relaxation in later years was golf, of which game he was a devotee. On his retirement he took a house at Forest Row within a stone's throw of the first tee of the beautiful Ashdown Forest course and, except when he came to London for board meetings of the National Provident Institution and the English and Scottish Investors, of which he was also a Director, he seldom missed a game there. His friends will remember the enjoyment he gave and found at the annual golf meetings, alternately at Brancaster and in Scotland, between the Actuaries Club and the Scottish Actuaries and also at the spring and autumn meetings of the Insurance Golfing Society.

Hovil was married in 1907 and leaves a widow and three daughters.

A. C. T.

\section{Deaths on Active Service}

David Maitland Watts, Student, Flight-Sergeant, R.A.A.F. Death assumed, 13 August 1942

Stanley James Elphick, Student, Flying Officer, R.A.F. Presumed killed as a result of air operations on 14 July 1943 .

ARNold George Noble, Student, Sergeant, A.I.F. Died a prisoner of war on I5 January 1944. 